(C) 2013, Elsevier. Licensed under the Creative Commons

Attribution-NonCommercial-NoDerivatives 4.0 International http://

creativecommons.org/licenses/by-nc-nd/4.0/

\title{
Do marine protected areas deliver flows of ecosystem services to support human welfare?
}

\author{
Tavis Potts ${ }^{a,{ }^{*}}$, Daryl Burdon ${ }^{b}$, Emma Jackson ${ }^{\mathrm{c}, \mathrm{d}}$, Jonathan Atkins ${ }^{\mathrm{e}}$, Justine Saunders $\mathrm{f}$, \\ Emily Hastings ${ }^{g}$, Olivia Langmead ${ }^{c}$ \\ a Scottish Association for Marine Science, Oban, Argyll PA37 1QA, UK \\ ${ }^{b}$ Institute of Estuarine \& Coastal Studies, University of Hull, Hull HU6 7RX, UK \\ c The Marine Biological Association of the UK, Citadel Hill, Plymouth PL1 2PB, UK \\ d Central Queensland University, School of Medical and Applied Sciences, Bryan Jordan Drive, PO Box \\ 1319, Gladstone, Qld. 4680, Australia \\ e Hull University Business School, University of Hull, Hull HU6 7RX, UK \\ ${ }^{f}$ Fugro EMU Limited, 1 Mill Court, Durley, Southampton SO32 2EJ, UK \\ g James Hutton Institute, Aberdeen AB15 8QH, UK
}

\begin{abstract}
This paper examines the potential relationships between the ecosystem services provided by the coastal and marine environment and the designation of marine protected areas. The hypothesis is that relationships exist between the provision of ecosystem services and the features protected by marine protected areas. It is considered that protection will maintain these features in good ecological condition and in some cases will restore ecological functioning with positive effects on the delivery of ecosystem services, as pressures upon the protected features are reduced. As the number of marine protected area designations grows, system-wide effects to communities from improvements in delivery of a range of ecosystem services may be realised. This paper provides a comparative analysis of the jurisdictional marine protected area policies proposed by the English, Welsh and Scottish Governments. It presents structured assessment matrices developed from the literature and expert opinion, of ecosystem service provision by marine protected habitats and species and applies the findings to a range of existing UK marine protected areas to demonstrate its relevance. The approach and case study findings are discussed within the wider context of marine ecosystem services and marine protected area management.
\end{abstract}

Keywords: Marine protected areas, Coastal governance, Ecosystem services, Habitats and species, Protected features

\section{The provision of ecosystem services and goods/benefits by MPAs}

Historically, the fundamental purpose of marine protected areas (MPAs) has been biodiversity conservation ${ }^{[1,2]}$. However, in the context of MPAs providing direct and indirect benefits for society [3], accounting for the export of ecosystem services from sites is increasingly recognised ${ }^{[4]}$. The importance of public perception and engagement with the planning and management of MPAs has also been acknowledged ${ }^{[5]}$. Ecosystem services are defined by the Millennium Ecosystem Assessment as the outputs of ecosystems from which people and society derive benefits ${ }^{[6]}$. Identifying and valuing ecosystem services from MPAs can highlight the services provided by marine ecosystems in general and can point to those that can potentially be enhanced or supported by MPA processes that improve system quality ${ }^{[7,8,9]}$ This includes local-scale provisioning services (i.e. marine resources such as fisheries) to large-scale and longer-term processes that support human welfare (e.g. carbon sequestration). Capturing the benefit flow from MPAs will inform the debate on the relationship between MPAs and human welfare, and inform the management of future sites, 
particularly in the context of multiple-use systems and human welfare questions in the adaptive management of marine systems [10]. This paper examines the potential relationships between the ecosystem services provided by the coastal and marine environment and the designation of marine protected areas. The hypothesis is that relationships exist between the delivery of ecosystem services and the features protected by marine protected areas. It is considered that protection will maintain these features in good ecological condition with positive effects on the delivery of ecosystem services. Understanding the portfolio of benefits derived from MPAs will improve planning and management, particularly in the context of making site specific or regional trade-offs over protected area designations and in understanding the ramifications of achieving the prescribed conservation objectives.

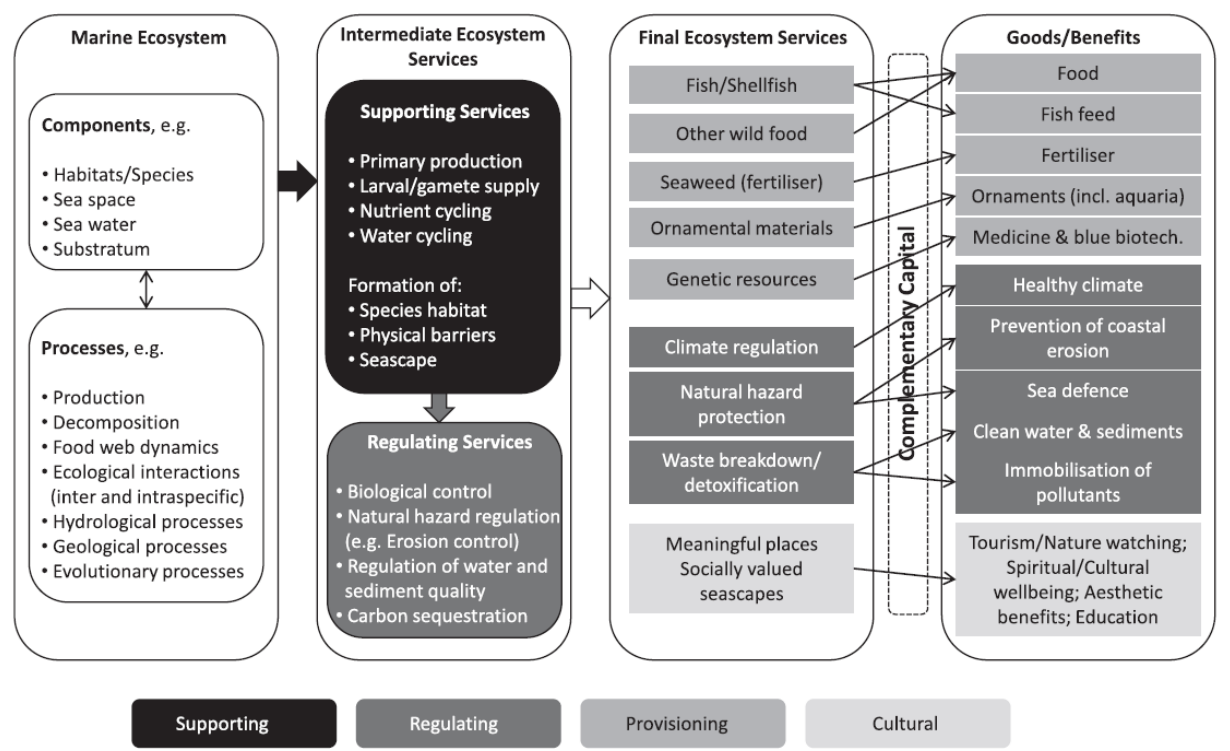

Figure 1: Schematic showing the intermediate and final ecosystem services and the goods/benefits provided by marine systems. Adapted from VNN report ${ }^{[17]}$.

In the UK, the National Ecosystem Assessment (UK NEA) provides a framework which can be used for examining ecosystem services in the context of MPAs [11]. The UK NEA analyses the UK's natural environment in terms of the benefits it provides to society and the nation's continuing prosperity. It is based on existing methods, especially those used for the Millennium Ecosystem Assessment ${ }^{[6]}$, the conceptual advances of The Economics of Ecosystems and Biodiversity (TEEB) ${ }^{[12]}$, those used to review ecosystem services in Europe ${ }^{[13]}$ and pioneering valuation and classification studies ${ }^{[14]}$. The framework adopted in this paper is consistent with previous classifications ${ }^{[15]}$ with the marine ecosystem classified according to a flow from ecosystem components and processes, to intermediate or final services, and goods/ benefits. Fig. 1 is adapted from the UK Valuing Nature Network initiative specifying the components of the marine ecosystem that provide ecosystem services and illustrating the flow of ecosystem services from the marine system to goods/benefits. The figure follows the UK NEA approach of classification for ecosystem services, capturing provisioning, regulating, cultural and supporting services. As highlighted in Fig. 1, fundamental marine 'components' (e.g. habitat, substratum) and 'processes' (e.g. production, food web dynamics) provide a range of intermediate supporting services (e.g. primary production, nutrient cycling and scenery) and 
regulatory services (e.g. natural hazard regulation and carbon sequestration). Intermediate services are indirect and are removed from human interaction, however, they provide the foundation for final ecosystem services. Final ecosystem services in this context are the end result of complex natural process that are available for human use and benefit. This includes resources for consumption (e.g. fisheries, ornamentals, seaweed for fertiliser or biofuel), critical coastal regulatory processes that sustain human communities (e.g. climate regulation, waste breakdown) and the production of socially valuable and meaningful places that provide the basis of cultural benefits (e.g. recreational, and aesthetic and spiritual). Goods/benefits are derived from final ecosystem services, and following the UK NEA approach, the focus here is on the biotic goods/benefits, excluding the abiotic goods/ benefits such as those realised from mineral extraction and energy development. A good/benefit is defined here as something of anthropocentric instrumental value, i.e. of both personal use (direct and indirect) and non-personal use (bequest, altruistic and existence) ${ }^{[16]}$. A good/benefit generally requires the input of complementary (human and physical) capital in order to realise benefits, for example, the final ecosystem service of fish/shellfish provides the good/benefit of food and complementary capital (e.g. labour, fishing vessels and energy) transforms this into a product for human consumption and health.

\section{What are the links between ecosystem services and MPA policy?}

Within the European Union, the establishment of a network of MPAs is required to meet obligations under a number of international agreements including the OSPAR Convention in the North East Atlantic, the World Summit for Sustainable Development and the Convention on Biological Diversity. The establishment of MPAs will also assist with the implementation of a number of European Directives, such as achieving Good Environmental Status under the EU Marine Strategy Framework Directive (2008/56/EC), Favourable Conservation Status for habitats and species under the EU Habitats Directive (92/43/EEC) and for wild bird species under the EU Birds Directive (2009/147/EC).

In the UK, the 2011 Marine Policy Statement ${ }^{[18]}$ publishes an overarching vision for the management of the UK ocean territory. It states the UK Government is committed to 'creating a UK-wide ecologically coherent network of MPAs as a key element of its wider work to recover and conserve the richness of our marine environment and wildlife' by 2012. This is made operational by the Marine and Coastal Access Act $2009{ }^{[19]}$ which establishes a marine planning regime and improves the protection of biodiversity by introducing additional MPA designations to complete the network in combination with European sites under the Habitats and Birds Directives. Under the UK Act, Marine Conservation Zones (MCZs) will protect nationally important marine wildlife, habitats, geology and geomorphology, and can be designated anywhere in English and Welsh inshore and UK offshore waters. In Scotland, the companion Marine (Scotland) Act $2010^{[20]}$ establishes the process for designation of Nature Conservation MPAs. There are distinct differences in the approaches adopted in the various national jurisdictions of the UK. 


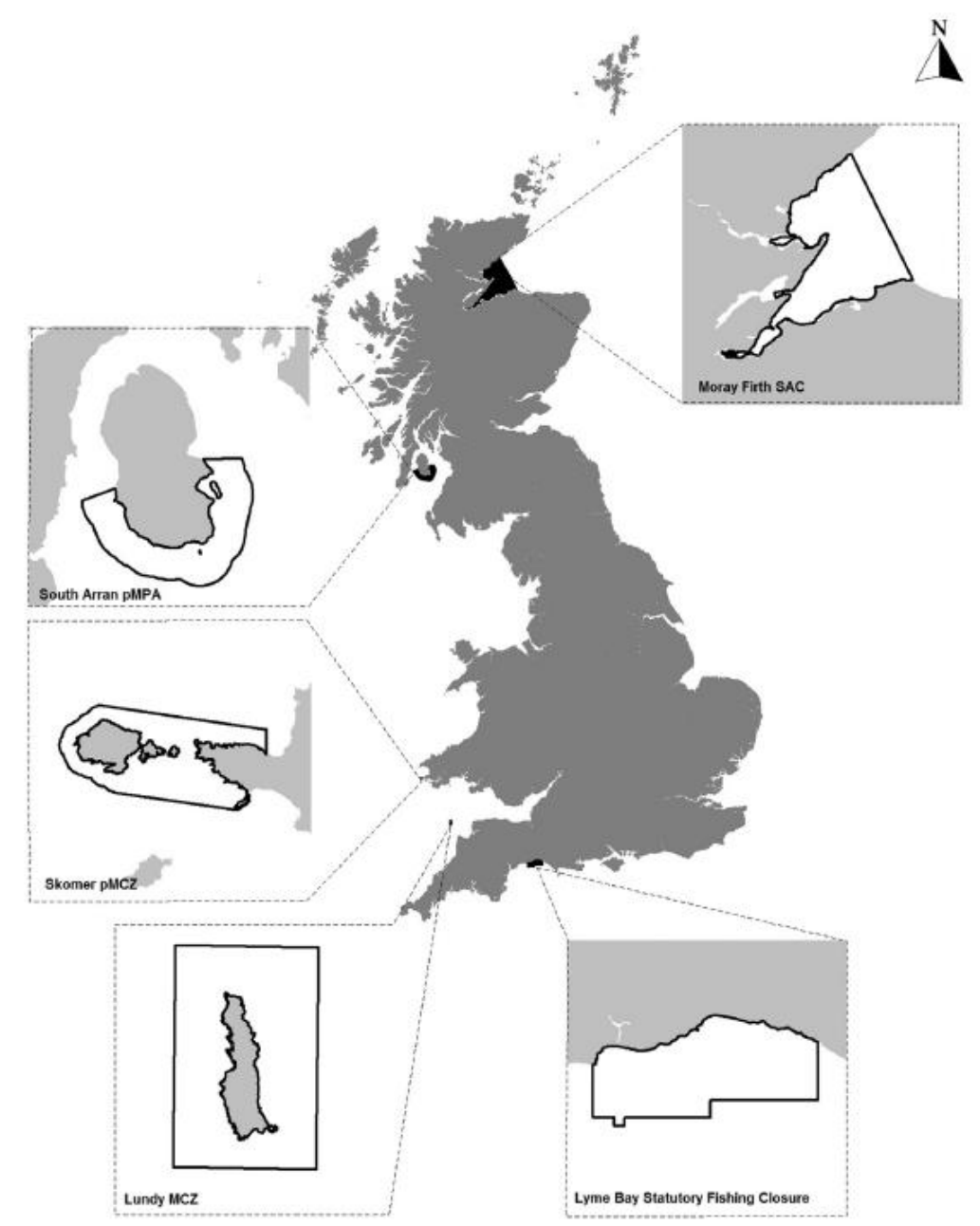

Figure 2: Case study sites for UK Marine Protected Areas.

The vision of the English MPA network is 'to recover and protect the richness of our marine wildlife and environment' ${ }^{21]}$ and contribute to the recovery, health and resilience of the wider environment. The focus of the English approach is not on protecting ecosystem services directly, but on biodiversity conservation. This is evident in the lists of Features of Conservation Importance (FOCl) which are dominated by rare, scarce or threatened species as opposed to those that are functionally important. However, some habitats of conservation importance have been selected for their importance in service provision, in particular their importance in the recruitment of fisheries (e.g. seagrass beds) or for supporting high biodiversity (e.g. maerl beds). How well ecosystem service provision is protected will depend on the features selected for each site, with each feature given a site-specific conservation objective of either maintaining current state or recover to favourable condition. These objectives focus on the area/population size and quality of the habitat, and not directly on ecosystem service provision. Within the MCZ network the concept of true 'no take zones/reserves' was initially construed to exist in the form of reference areas, which have the potential to demonstrate spill-over and provisioning services from MPAs. However the reference area concept was essentially delayed and removed from policy implementation by 
the UK Government in December 2012 citing a 'lack of evidence' that reference areas contribute to the objectives of UK network ${ }^{[22] .}$

By contrast, the Welsh Government's approach to using the new MCZ power is to supplement the levels of protection within existing MPAs rather than create new sites, with ecosystem recovery based on a limited number of highly protected sites. The intention is for these sites to function as naturally as possible in order to maximise the contribution they make to ecosystem recovery and resilience. It is argued the best way of achieving this is to afford the sites a high level of protection; that is protection from extraction and deposition of living and non-living resources plus all other damaging or disturbing activities. The emphasis on biodiversity, functioning and resilience is more closely aligned with an ecosystem services approach than a focus on lists of features. High levels of protection within the Welsh MCZs may enhance provisioning services preferentially, and create productive areas where species 'spill-over' into the surrounding waters.

The MCZ process in England and Wales will be complimented by activities in Scotland under the Marine (Scotland) Act $2010^{[20]}$ and with emerging legislation in the Northern Ireland Assembly in its territorial waters; the latter is still in an early phase and will not be addressed by this paper. The designation process for MPAs in Scotland aims to protect marine biodiversity and ecosystems to ensure that natural environment, and the diversity of industries which depend upon it, is safeguarded for the future' (The Scottish Government,

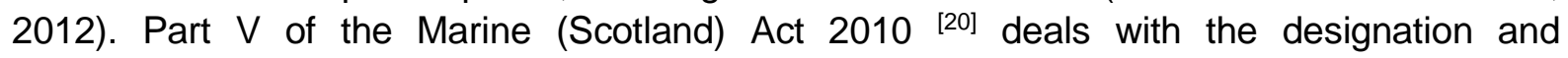
management of MPAs. While nature conservation MPAs are designed foremost for conservation, the principal theme is that of sustainable development. Section 68 of the Act highlights that nature conservation MPAs should consider mitigation of climate change (a regulatory ecosystem service) and that Ministers may 'have regard' to social and economic consequences of designation. While this infers negative consequences, it could be interpreted that positive changes to human welfare from improved ecosystem service provision could inform the designation process. Further evidence exists of the dual nature of MPAs to achieve conservation and deliver ecosystem service functions. The Strategy for Marine Nature Conservation in Scotland's Seas ${ }^{[23]}$ identifies that industries and communities 'depend on a range of ecosystem services delivered by marine biodiversity' and that spatial protection can maximise the flow of benefits to society. The Strategy notes that public understanding and decisions around marine biodiversity are contingent upon improved understanding of the range of economic, climate change resilience, and societal benefits from marine systems.' The selection guidelines allow for the inclusion of sites which provide a flow of services. For example guideline 1c states that "this guideline should include consideration of features or locations providing ecosystem services which underpin key human activities/use of the marine environment."

Thus in MPA designation by the devolved nations, each has approached its obligations to contribute to a UK-wide ecologically coherent network of MPAs in different ways. In England, the focus has been on biodiversity conservation with the proposed establishment of a new suite of MCZs which will complement the existing network of English MPAs. The Welsh government has proposed an increase in the level of protection of a number of existing MPAs in order to protect biodiversity, functioning and resilience. In Scotland a new suite of MPAs is proposed which has the dual focus of nature conservation and delivery of ecosystem service functions within the principal theme of sustainable development. The English and Scottish 
authorities have released draft assessments of proposed networks in December 2012 outlining the initial designs, currently subject to public consultation ${ }^{[22,24]}$. Wales launched a consultation on 10 proposed fully protected MPA sites in late 2012, has been reviewing the approach to the network in $2013^{[25]}$, and at the time of writing is reconsidering its approach to meeting its obligations.

\section{Methodology: assessment of ecosystem services from UK habitats and species}

As part of the NERC-funded Valuing Nature Network (VNN) project on coastal ecosystem services (January 2012-March 2013) the authors developed two matrices that identify specific ecosystem services from UK protected habitats and species, subjected them to internal and external peer review through an expert based process, and applied them to five case study sites across UK jurisdictions. The objective was to categorise, classify and assess the provision of ecosystem services from protected sites, to further support deliberation over designations of new sites under the described processes and inform management arrangements. The matrices (Figs. 3 and 4) were inspired from the conceptual framework provided in Fig. 1 but were adapted after deliberations and expert peer-review over the duration of the project. Initial guidance for constructing the matrices was drawn from a Natural England project [7] which developed a snapshot of the ecosystem services provided by a range of English habitats and species for which MCZs will be designated. Building on this approach, the research extends its coverage to Welsh and Scottish MPAs, and features designated under the EU Habitats Directive, to ensure full coverage across the proposed UK network.

The shading of each cell within the matrices represents an indication of the relative importance of each feature in providing the respective ecosystem service (darker being more important, lighter less important). Some features are more important than others in providing a particular service and therefore scores should be interpreted relative to all the features. For example, whilst a number of marine habitats may contribute a climate regulation service, the most important habitats are 'coastal saltmarshes and saline reed beds' and 'intertidal sediments dominated by aquatic angiosperms'. A cell left uncoloured reflects a gap in current understanding. The number within each cell relates to the level of confidence in the evidence. Where there was scientific, UK-relevant, peer-reviewed evidence establishing a link between a feature and a service, the level of confidence was rated 3. A confidence level of 2 indicated support from non-peer reviewed grey literature or overseas literature that was not specific to either the UK context or the particular species (e.g. a closely related species) in question. Where the evidence was based on expert opinion then this was given a confidence rating of 1 . The matrices focus on intermediate services and goods/benefits, separate scoring of final ecosystem services was deemed unnecessary and would reduce the clarity and manageability of the matrix. Final services directly link to goods/benefits through complementary capital, their direct contributions are captured through the inclusion of goods/benefits and this avoids the potential for double counting.

The expert based approach was iterated through several rounds within the VNN including workshops in Norwich and Plymouth, through circulation amongst network members and affiliated institutions, and by posting of the draft matrices for comment on the VNN website (http://www.valuing-nature.net/). This attracted comment from several international experts in 
specific habitats or wider ecosystem services. This paper acknowledges that the matrices are a starting point for further research on the MPA contribution to ecosystem services, but also represents a unique snapshot at the UK scale of the ecosystem service contribution made by protected habitats and species. To contextualise the matrices onto real MPA sites, the authors identified five UK case studies based on geographical spread and the management of particular habitats and species (see Fig. 2). The case studies represent diverse MPA sites from differing UK jurisdictions and MPA regulatory drivers. This includes existing European Habitats Directive sites and sites put forward for public consultation under the Marine and Coastal Access Act and the Marine (Scotland) Act. The case studies elaborate on combinations of ecosystem service outputs from the matrices in the context of regional sites and their management. 




Figure 3: Relative importance of designated broad scale and fine scale habitats in providing intermediate ecosystem services and goods/benefits. 


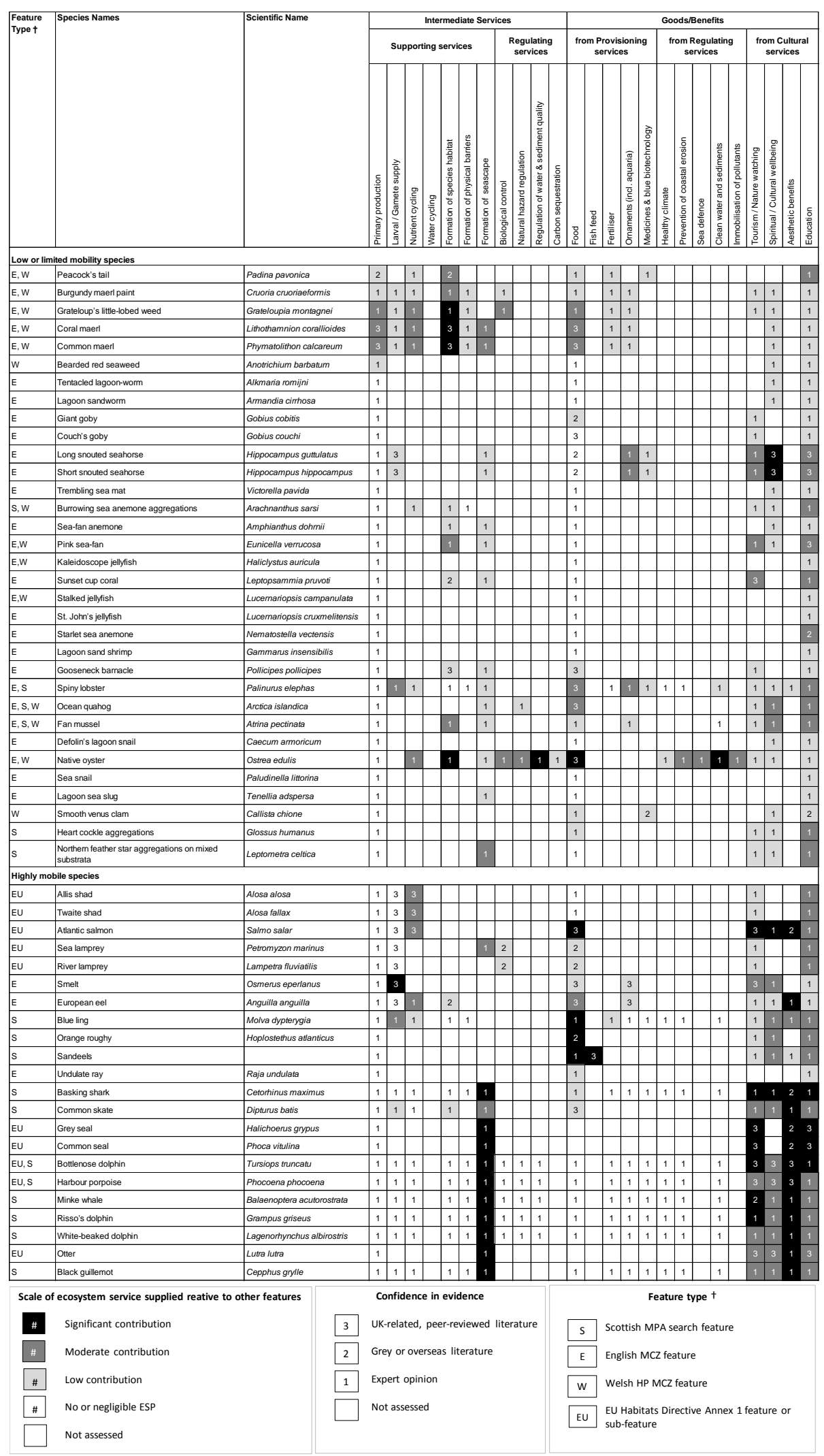

Figure 4: Relative importance of designated species in providing intermediate ecosystem services and goods/benefits. 


\section{Results}

The matrices present an overview of the intermediate ecosystem services and goods/benefits provided by different marine features. In terms of the habitat assessment (Fig. 3) understanding derives predominantly from expert opinion and the grey/international literature. There is reasonable scientific understanding of contributions to ecosystem services at the scale of intermediate supporting and regulatory services. At a species level (Fig. 4) the knowledge base is considerably less over the contribution of individual species to specific ecosystem services. The exceptions include peer-reviewed literature on the contribution of maerl, shad, salmon and lamprey to supporting services, and the contributions of marine mammals to cultural services such as tourism, nature watching, cultural wellbeing and aesthetic benefits.

The matrices can be read horizontally to observe the contribution of a particular habitat or species to overall ecosystem services provision, or vertically to identify the mix of services from protected areas with a multitude of habitats and species. Fig. 3 indicates that broadscale habitats provide important intermediate (supporting and regulating) services such as the formation of species habitat and physical barriers. All habitats contribute to supporting services to varying degrees, such as primary production and larval/gamete supply, however, this is often related to a particular component or quality of the habitat. For example, intertidal sediments may support natural hazard regulation where they form natural barriers such as sand banks. Similarly, the formation of species habitats from intertidal rock will be strongly dependent on the nature (composition and complexity) of the substratum itself. As a consequence, it is more straightforward to identify and score, with a greater level of confidence, the more specific habitat features in the bottom half of Fig. 3 than the generic broadscale habitats.

Fig. 3 also specifies the incidence of multifunctional habitats where broad scale or specific features provide supporting, regulating, provisioning and cultural services across the intermediate and benefits categories. These systems are highly productive, visible, and coastal and are usually attributed with the best knowledge base as a result of studies published in the peer-reviewed literature. Eight habitat assemblages are apparent from the data, and comprise broadly defined intertidal systems: coastal salt marshes; intertidal sediments dominated by aquatic angiosperms; subtidal macrophyte-dominated sediment; low or variable salinity habitats; seagrass beds; sea loch egg wrack beds; kelp and seaweed communities on sublittoral sediment; and tide-swept algal communities. These multifunctional habitats are important for the management of MPAs in that they conserve productive systems that provide a diversity of ecosystem service flows.

Some goods/benefits are provided by particular species, rather than habitats as a whole, such as ornaments (including aquaria), medicine and blue biotechnology. Knowledge of species contribution to ecosystem service provision is limited and confined to expert opinion. What is apparent from the data is that certain species play key roles in supporting, provisioning and cultural services but rarely does a species play a consistent role across all types of ecosystem service, goods/benefits. What is particularly apparent is that many species that are considered charismatic play an important role in providing cultural services including spiritual and cultural wellbeing, and tourism/nature watching. Species such as the long and short snouted seahorse, Atlantic salmon, bottlenose dolphin, grey and common 
seal, basking shark and minke whale all contribute to cultural goods/benefits. It is likely that the social importance of these animals is a consideration for their presence in MPA designation processes.

\section{Case studies linking MPAs with ecosystem services}

To ground the matrices in real examples the authors present five case studies selected to reflect both the geographical range of MPAs across UK jurisdictions and the wide variety of existing and proposed MPA management approaches. The case studies reflect MPAs that have been designated under European, UK or Scottish instruments, or are currently moving through the process of consultation as proposed or recommended sites. This demonstrates the complexity and overlap of policy that designates MPA processes at local (MPA sites), jurisdictional (e.g. Scotland), national (UK) and international (EU and global) scales. The case studies summarised in Table 1, highlight that ecosystem service provision will vary across spatial scales and across configurations of habitats, species and local management arrangements. While this paper purposely does not follow upon valuations of services from MPAs, its contribution is in understanding how different mixes of features can lead to service flows in MPAs at the UK scale. It identifies, through an expert process, the relative contribution (no/negligible, low, moderate or significant) of ecosystem services across different habitats and species in the UK. Understanding the different flows is an important policy question with ramifications for MPA management. For example, a recent Scottish Government report on the progress of the MPA network ${ }^{[18]}$ valuing the direct and indirect use and non-use benefits is important to understanding the full mosaic of services provided by MPAs and their long term benefits to society.

In the Moray Firth SAC (Table 1) sub-tidal sandbanks contribute to the delivery of a range of services including supporting a number of species of algae and invertebrates (i.e. formation of species habitat); providing natural hazard regulation (i.e. erosion control); nutrient cycling; fish feed; and spawning grounds and nursery areas for sandeels and juvenile fish, many of which are commercially exploited. This productivity forms an important food source for marine mammals and sea birds which offer cultural services via, for example, tourism/nature watching and education. The management plan acknowledges that the bottlenose dolphin is an important local and national asset, not only for reasons of biodiversity conservation, but also because of the cultural services they provide including education, tourism, and nature watching [26]. The benefits of cultural services by Moray Firth bottlenose dolphins are expressed by the value in local tourism. In a study for the Moray Firth Partnership ${ }^{[27]}$ the total income from direct tourism expenditure in Scotland reliant solely on the Moray Firth bottlenose dolphin population, was considered to be at least $£ 4$ million; it also provided approximately 202 full time jobs.

The South Arran region is the proposed site of a nature conservation MPA under the Marine (Scotland) Act 2010 (Table 1). The site has been proposed through a community designation process that fits within the broader scientific site selection processes under the Act. The site is considered regionally significant within the Firth of Clyde ecosystem and would seek to protect nationally important biodiversity features such as burrowed mud, kelp and seaweed communities, maerl beds, seagrass beds, and shallow tide-swept coarse sands with burrowing bivalves ${ }^{[28]}$. The site is also noted as an important historical area for herring and cod spawning grounds ${ }^{[28]}$. A number of services flow from the habitat assemblages from this diverse site. Under the current MPA proposal, habitats in the site would aim to be recovered 
to a favourable condition. Recovery would strengthen supporting services such as primary production, larval/gamete supply, nutrient cycling, and the formation of species habitat and physical barriers; regulating services including carbon sequestration, natural hazard regulation and the regulation of water and sediment quality; provisioning services in particular the delivery of food, fertiliser and medicines (incl. blue biotechnology); and cultural services including spiritual/cultural wellbeing and aesthetic benefits (the site is home to an internationally significant religious community), tourism, and education. There is evidence of multi-functional habitats at the site that provide important services. For example: maerl beds, and maerl or coarse shell gravel with burrowing sea cucumbers provide significant levels of habitat formation and species diversity; and kelp and seaweed communities on sub-littoral sediments provide significant nutrient recycling functions, climate regulation and emissions reduction, and influence cultural benefits such as tourism/nature watching. The local community has expressed support for using the MPA designation to develop sustainable fishing practices, building upon the provisioning benefits established from spatial protection. Ecological communities within the smaller Lamlash Bay No Take Zone (NTZ), within the proposed South Arran MPA, have been found to be more diverse and abundant than outside, and scallop populations inside the NTZ are made up of older, larger, and greater numbers of individuals ${ }^{[29]}$. With extension of the proposed site now covering a significantly greater area of Arran and the Firth of Clyde, the supporting and provisioning services would deliver greater benefits if key pressures such as scallop dredging can be managed.

In the Skomer case study (Table 1) a report for the Countryside Council for Wales (now part of Natural Resources Wales) ${ }^{[30]}$ identifies and quantifies some of the ecosystem services, goods/ benefits secured for the Marine Nature Reserve (MNR) for 2011. According to unpublished reports, the scallop population has increased 'at least four fold and perhaps more than eight fold' over the first 20 years of its designation (CCW Press Release, 20 April 2010). Commercial fishing is reported to involve potting, with 11 boats visiting the MNR (half of them accounting for the bulk of the activity) and with $75 \%$ of the MNR area potted in 2011 [30]. Evidence points to recreational services provided by the site with records of 1579 diver days (with Lucy wreck located within the MNR a popular dive site), 454 recreational craft visits made in addition to commercial sightseeing boats passing through the site, and 630 anglers (308 shore and 322 boat anglers) in 2011 [30]. Research activities are significant with involvement of UK and international universities and several government agencies and wider educational interest is evidenced by the site hosting visits of 'popular' television programming during 2011.

In the Lundy MCZ case study (Table 1), the conservation and restoration of important habitat and species features were included principally to improve the ecological coherence of the UK network; a number of ecosystem services and goods/benefits were identified. The FOCI habitat of mud in deep water has been highlighted as moderately important for a number of intermediate supporting services (larval/gamete supply, nutrient cycling, formation of species habitat) and goods/benefits gained from provisioning services (food, fish feed and ornamental material (incl. aquaria)), regulating services (clean water and sediments, immobilisation of pollutants) and cultural services (education). The FOCl species, spiny lobster, is considered moderately important for intermediate supporting services (larval/gamete supply), and goods/benefits gained from both provisioning services (food, ornamentals (incl. aquaria)), and cultural services (education). Monitoring of the MCZ, in particular within the Lundy NTZ, has shown that there is 
the potential for a spill-over benefit for the surrounding lobster population ${ }^{[31]}$ and this is currently being investigated by the Devon and Severn Inshore Fisheries Conservation Authority. An improvement in the condition of the overall site features, as a result of MCZ designation, could improve the quality of diving at the site and may lead to an increase in wildlife visits; the provision of such services however is not reflected by the FOCl listed in Table 1.

Table 1: The features present within five case study UK MPAs, the key ecosystem services (considered of significant or moderate importance) provided, and the level of protection/ management in each site.

\begin{tabular}{|c|c|c|}
\hline Features present in the MPA & Key ecosystem services provided by the MPA & Level of protection/management provided by the MPA \\
\hline \multicolumn{3}{|c|}{ Case 1: Moray Firth Partnership, Scotland. Special Area of Conservation (EU Habitats Directive) } \\
\hline $\begin{array}{l}\text { Habitats-Sandbanks which are slightly covered by } \\
\text { sea water all the time (offshore subtidal sands, } \\
\text { subtidal mixed sediments). }\end{array}$ & $\begin{array}{l}\text { Nutrient cycling; formation of species habitat; food; fish } \\
\text { feed; medicines and blue biotechnology; formation of } \\
\text { seascape; tourism/nature watching; spiritual/cultural }\end{array}$ & $\begin{array}{l}\text { Current Level of Protection-the designation of the SAC } \\
\text { does not preclude any damaging activities. } \\
\text { Recommended Management Option-to meet }\end{array}$ \\
\hline Species-Bottlenose dolphin (Tursiops truncates). & wellbeing; aesthetic benefits; and education. & $\begin{array}{l}\text { conservation objectives. Management of Activities- } \\
\text { Activities managed via SAC management plan. }\end{array}$ \\
\hline \multicolumn{3}{|c|}{ Case 2: South Arran, Scotland. Proposed Nature Conservation Marine Protected Area (Marine Scotland Act 2010) } \\
\hline $\begin{array}{l}\text { Habitats-Burrowed mud; kelp and seaweed } \\
\text { communities on sublittoral sediments; maerl beds; } \\
\text { maerl or coarse shell gravel with burrowing sea } \\
\text { cucumbers; seagrass beds; shallow tide-swept } \\
\text { coarse sands with burrowing bivalves. }\end{array}$ & $\begin{array}{l}\text { Primary production; larval/gamete supply; nutrient } \\
\text { cycling; formation of species habitat; formation of } \\
\text { physical barriers; biological control; natural hazard } \\
\text { regulation; regulation of water and sediment quality; } \\
\text { carbon sequestration; food; fertiliser; medicine (incl. }\end{array}$ & $\begin{array}{l}\text { Proposed Level of Protection-Prohibit damaging and } \\
\text { unsustainable fishing practices; encourage sustainably } \\
\text { managed fishing methods; encompasses current No } \\
\text { Take Zone, Lamlash Bay. Recommended Management } \\
\text { Option-protect existing sensitive habitats and species, }\end{array}$ \\
\hline Species-Ocean quahog (Arctica islandica). & $\begin{array}{l}\text { blue biotechnology); healthy climate; prevention of } \\
\text { coastal erosion; sea defence; clean water and sediments; } \\
\text { immobilisation of pollutants; tourism/nature watching; } \\
\text { spiritual/cultural wellbeing; aesthetic benefits; and } \\
\text { education. }\end{array}$ & $\begin{array}{l}\text { allowing regeneration of degraded seabed habitats. } \\
\text { Management of Activities-proposed MPA will allow for } \\
\text { the effective management of existing and predicted } \\
\text { pressures. }\end{array}$ \\
\hline \multicolumn{3}{|c|}{$\begin{array}{l}\text { Case 3: Skomer, Wales. Marine Nature Reserve under the Wildlife and Countryside Act 1981, part of Pembrokeshire Special Area of Conservation (EU Habitats Directive); } \\
\text { and being considered as a proposed Marine Conservation Zone (Marine and Coastal Access Act 2009) }\end{array}$} \\
\hline $\begin{array}{l}\text { Habitats-High energy circalittoral rock; high energy } \\
\text { shallow water rock; moderate energy shallow water } \\
\text { rock; high energy intertidal rock; moderate energy } \\
\text { intertidal rock; intertidal coarse sediment; intertidal } \\
\text { sand and muddy sand; subtidal coarse sediment; } \\
\text { subtidal mixed sediments; subtidal sand; fragile } \\
\text { sponge and anthozoan communities on subtidal } \\
\text { rocky habitats; mud habitats in deep water; subtidal } \\
\text { mixed muddy sediments; subtidal rock with ross } \\
\text { 'coral'; tide swept channels. }\end{array}$ & $\begin{array}{l}\text { Primary production; larval/gamete supply; nutrient } \\
\text { cycling; formation of species habitat; formation of } \\
\text { physical barriers; formation of seascape; natural hazard } \\
\text { regulation; food; fish feed; prevention of coastal } \\
\text { erosion; sea defence; clean water and sediments; } \\
\text { immobilisation of pollutants; tourism/nature watching; } \\
\text { and aesthetic benefit. }\end{array}$ & $\begin{array}{l}\text { Proposed Level of Protection-A highly protected MCZ } \\
\text { however all Welsh pMCZs are currently under review. } \\
\text { Recommended Management Option-Maintain in } \\
\text { favourable conservation status. Management of } \\
\text { Activities-Statutory nature reserve managed under } \\
\text { bylaws from Natural Resource Wales (formerly the } \\
\text { Countryside Council for Wales) and Wildlife and } \\
\text { Countryside Act 1981. User Regulations Fishing } \\
\text { activities managed under inshore fishing regulations } \\
\text { through the Welsh Government. }\end{array}$ \\
\hline \multicolumn{3}{|c|}{ Case 4: Lundy, England. Marine Conservation Zone (Marine and Coastal Access Act 2009) } \\
\hline $\begin{array}{l}\text { Habitats-Mud habitats in deep water. } \\
\text { Species-European spiny lobster (Palinurus elephas). }\end{array}$ & $\begin{array}{l}\text { Larval/Gamete supply; Nutrient cycling; Formation of } \\
\text { species habitat; food; fish feed; ornaments (incl. } \\
\text { aquaria); clean water and sediments; immobilisation of } \\
\text { pollutants; and education. }\end{array}$ & $\begin{array}{l}\text { Current Level of Protection-all habitats and wildlife are } \\
\text { protected within the MCZ boundaries. Recommended } \\
\text { Management Option -Recover to favourable condition. } \\
\text { Management of Activities-A zoning scheme is in place } \\
\text { within the MCZ to manage all activities. }\end{array}$ \\
\hline \multicolumn{3}{|c|}{$\begin{array}{l}\text { Case 5: Lyme Bay, England. Statutory fishing closure (The Lyme Bay Designated Area (Fishing Restrictions) Order 2008) and candidate Special Area of Conservation (EU } \\
\text { Habitats Directive) }\end{array}$} \\
\hline $\begin{array}{l}\text { Habitats-Reefs. } \\
\text { Species-Pink sea fan (Eunicella verrucosa); Sunset } \\
\text { cup coral (Leptopsammia pruvoti). }\end{array}$ & $\begin{array}{l}\text { Primary production; nutrient cycling; larval/gamete } \\
\text { supply; formation of species habitat; formation of } \\
\text { physical barriers; formation of seascape; biological } \\
\text { control; natural hazard regulation; regulation of water } \\
\text { and sediment quality; carbon sequestration; food; } \\
\text { medicine (incl. blue biotechnology); healthy climate; } \\
\text { prevention of coastal erosion; sea defence; clean water } \\
\text { and sediments; tourism/nature watching; spiritual/ } \\
\text { cultural wellbeing; education. }\end{array}$ & $\begin{array}{l}\text { Current Level of Protection-No bottom towed fishing } \\
\text { gear. Recommended Management Option-Recover to } \\
\text { reference condition. Management of Activities- } \\
\text { Remains open to other types of human activity for } \\
\text { example sea anglers, scuba divers, other recreational } \\
\text { users and fishers using static gear such as pots and } \\
\text { nets. }\end{array}$ \\
\hline
\end{tabular}

In the Lyme Bay case study (Table 1), the provision of supporting services such as primary production, nutrient cycling and formation of species habitat (for example for commercially and culturally important species) was very much embedded in the reason for designating the site, although local (and even national) scientific evidence of these functional roles of reef habitat are scarce. Ongoing monitoring of the recovery of the reef has shown that, in addition to an increase in the structural fauna of the reef and subsequent increase in 'habitat provision' the densities of scallops within the area showed an expected increase which is likely to have

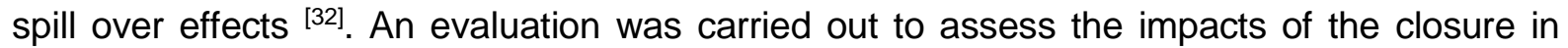
socio-economic terms ${ }^{[33]}$. The report focused on direct services and showed that landings 
data of all gear types (static gear is still used in the closed area) increased following the closure implying the loss of access to fishing grounds in the closed area has been compensated for by the remaining fishing grounds ${ }^{[33]}$. The protection of the reefs has a positive benefit in terms of protecting some of the most valuable sites for the leisure and recreation industry (primarily sea angling and diving) ${ }^{[34]}$. Lyme Bay has been used as a case study to examine how indirect ecosystem services may be incorporated into MPA management ${ }^{[35]}$. The study promoted a 'service orientated' approach following the ecosystem cascade theory ${ }^{[36]}$ mapping ecosystem services (in this case nutrient cycling, bioremediation of waste and gas and climate regulation) with the relevant ecosystem processes (e.g. energy fixation and transfer and the burial and enhancement of microbial decomposition) and linking these to mapped benthic organisms within the Bay. The study showed that whilst MPA planning focuses on the protection of specific marine habitats and species, ecosystem services do not neatly map onto the presence of a particular species [36]. There is no doubt that key ecosystem providers do exist, however unless they are scarce or threatened they may not be the focus of MPA designation, but may still benefit from it.

\section{Discussion and conclusion}

The inclusion of ecosystem service concepts into MPA designation and management is at an early stage in the UK. The priority for designation is one of protecting nationally 'important' habitats and species - usually those that are considered endangered, threatened or rare-and the extent of the MPA network is currently subject to fierce political debate. While ecosystem service concepts are not completely absent from the policy dialogue, for example in Scotland guidelines for incorporating ecosystem services into designation protocols do exist ${ }^{[37]}$, they currently appear to be at the margins of the existing process in other UK jurisdictions. In the Scottish case policy makers appear to recognise, at least conceptually, that the ecosystem services concept is important in MPA management. However there is little evidence to date that suggests any sites in the proposed UK network have been selected explicitly on the basis of the contribution of ecosystem services supporting societal benefits. If habitats are to be afforded a priority for conservation other than scarcity or status, it could conceivably be along the lines of diversity and/or intensity of ecosystem service provision. This prioritisation would have the potential to influence the range of management measures deployed within MPAs, with stricter measures intended for MPAs that produce a wide range of benefits for society.

Underlying the use of the ecosystem services approach to inform MPA designation is the paucity of data. The availability of data on the functioning (i.e. what ecological configurations and levels of biodiversity provide what services) and value of those services to society is a major obstacle to the implementation of policy. As shown in Figs. 3 and 4, a comprehensive dataset does not yet exist within the UK (and this is even more pronounced internationally) about service flows and goods/benefits from habitats and species. Future work on establishing a baseline dataset on ecosystem service flows from coastal and marine systems in general, MPAs in particular and generating monetary-and non-monetary valuations is important for informing both the ongoing dialogue about how ecosystem services can be incorporated within conservation efforts, and management practice.

The decision on the shape of the UK network of MPAs is not yet resolved with designations currently under public consultation ${ }^{[22,23]}$ (in 2013). Once the network is in place it will be important to monitor not only the status of designated marine habitats and species but also the 
flow of regulating, provisioning and cultural services and goods/benefits from sites and the influence of management configuration on service delivery. The way in which the pressures in MPAs are managed will determine the scale and type of flows from them and how they relate to areas outside the network. While management plans for the formative UK network will not be negotiated for at least 12 months, understanding the pressures upon features in relation to different ecosystem services could influence the type of management responses that are elaborated in the MPA.

The ecosystem services concept provides a basis for identifying the benefits that humans obtain from marine systems. This paper highlights that while the data on identifying and evaluating ecosystem service flows is incomplete, the concept is important in understanding our relationship to coastal systems and the benefits of conservation and protection. In terms of MPAs, few designation processes have explicitly taken the ecosystem services concept into account in terms of site selection despite recognition of its importance. This paper argues that this is due to a lack of information and policy guidance rather than explicit omission, and that future management debates around MPAs should take into account the extent and quality of supporting, regulatory, provisioning and cultural ecosystem services, and the goods/benefits provided for society as an inherent feature of the MPA designation and management process.

\section{Acknowledgements}

The authors wish to thank the Natural Environment Research Council (NERC) for funding the Valuing Nature Network (VNN) and to colleagues within the VNN, in particular within the Coastal Management VNN, for useful discussions which have contributed to the production of this manuscript. The authors would also like to thank the anonymous reviewers who provided constructive comments on the manuscript.

\section{References}

[1] Edgar G. Does the global network of marine protected areas provide an adequate safety net for marine biodiversity? Aquatic Conservation: Marine and Freshwater Ecosystems $2011 ; 21: 313-6$.

[2] Angulo-Valdes, B.G. Hatcher. A new typology of benefits from marine protected areas. Marine Policy 2010; 34(3):635-44.

[3] Caveen AJ, Gray TS, Stead SM, Polunin NVC. MPA policy:what lies behind the science? Marine Policy 2013; 37:3-10.

[4] Roncin N, Alban F, Charbonnel E, Crec'hriou R, De la Cruz Modino R, Culioli J-M, et al. Uses of ecosystem services provided by MPAs: how much do they impact the local economy? A southern Europe perspective Journal for Nature Conservation 2008; 16: 25670 .

[5] Voyer M, Gladstone W, Goodall H. Methods of social assessment in Marine Protected Area planning: is public participation enough? Marine Policy 2012; 36:432-9.

[6] Millennium Ecosystem Assessment (MEA). Millennium Ecosystem Assessment Ecosystems and Human Wellbeing Biodiversity Synthesis. Washington DC: Island Press; 2005. 
[7] Fletcher S, Saunders J, Herbert R, Roberts C. Description of the ecosystem services provided by broad-scale habitats and features of conservation importance that are likely to be protected by Marine Protected Areas in the Marine Conservation Zone Project area. Natural England [online], 〈http:// publications.naturalengland.org.uk/file/300602); 2011.

[8] Roberts CM, Branch G, Bustamante RH, Castilla JC, Dugan J, Halpern BS. Application of ecological criteria in selecting marine reserves and developing reserve networks. Ecological Applications 2003; 13(1):S215-28.

[9] Kenter JO, Bryce R, Davies A, Jobstvogt N, Watson V, Ranger S., et al. The value of potential marine protected areas in the UK to divers and sea anglers. UNEPWCMC, Cambridge, UK [online], 〈http://uknea.unep-wcmc.org/LinkClick.aspx? fileticket=Mb8nUAphh\%2bY\%3d\&tabid=82); 2013.

[10] Agardy T, Bridgewater P, Crosby MP, Day J, Dayton PK, Kenchington R, et al. Dangerous targets? Unresolved issues and ideological clashes around marine protected areas Aquatic Conservation: Marine and Freshwater Ecosystems 2003; 13:353-67.

[11] Mace GM, Bateman I, Albon S, Balmford A, Brown C, Church A., et al. Chapter 2: conceptual framework and methodology. UK National Ecosystem Assessment. The UK NEA technical report. Cambridge: UNEP-WCMC; 2011.

[12] De Groot RS, Fisher B, Christie M, Aronson J, Braat L, Haines-Young R, et al. Integrating the ecological and economic dimensions in biodiversity and ecosystem service valuation. In: Kumar $\mathrm{P}$, editor. The economics of ecosystems and biodiversity: ecological and economic foundations. London and Washington: Earthscan; 2010 ([chapter 1]).

[13] Fitter A, Elmqvist T, Haines-Young R, Potschin M, Rinaldo A, Setala $H$, et al. An assessment of ecosystem services and biodiversity in Europe. Issues in Environmental Science and Technology 2010; 30:1-28.

[14] Fisher B, Turner RK. Ecosystem services: classification for valuation. Biological Conservation 2008; 141:1167-9.

[15] Fisher B, Turner RK, Morling P. Defining and classifying ecosystem services for decision making. Ecological Economics 2009; 68:643-53.

[16] Turner RK, Bateman IJ, Adger N, editors. Dodrecht. Kluwer; 2001.

[17] Turner K, Mee L, Elliot M, Burdon D, Atkins JP, Saunders J., et al. Coastal zone ecosystem services: from science to values and decision making, a conceptual framework. Unpublished report of the NERC-funded valuing nature network. Norwich: UEA; January 2013.

[18] HM Government, Northern Ireland Executive, Scottish Government, Welsh AssemblyGovernment. UK Marine Policy Statement. London, UK: The Stationery Office [online], 〈https://www.gov.uk/government/publications/uk-marinepolicy-statement $\rangle ; 2011$.

[19]HM Government Marine and Coastal Access Act 2009 [online], 〈http://www. legislation.gov.uk/ukpga/2009/23/contents).

[20] Scottish Government. Marine (Scotland) Act (2010) [online], 〈http://www. legislation.gov.uk/asp/2010/5/pdfs/asp 20100005 en.pdf $\rangle.$ 
[21] Natural England \& the Joint Nature Conservation Committee. Marine conservation zone project: ecological network guidance. Sheffield and Peterborough, UK [online], 〈http://jncc.defra.gov.uk/pdf/100705 ENG v10.pdf $; ; 2010$.

[22]Department for Environment, Food and Rural Affairs (DEFRA). Marine Conservation Zones: Consultation on proposals for designation in 2013 December 2012. London, UK: Department of Environment, Food and Rural Affairs [online], 〈http://www.defra.gov.uk/consult/2012/12/13/marine-conservationzones-1212/〉; 2012.

[23] Scottish Government. The strategy for marine nature conservation in Scotland's Seas. Edinburgh: Marine Scotland [online], 〈http://www.scotland.gov. uk/Topics/marine/marineenvironment/Conservationstrategy/marineconstrat egy $; 2011$.

[24] Scottish Government. Report to the Scottish Parliament on progress to identify a Scottish network of marine protected areas. Edinburgh: Marine Scotland [online], 〈http://www.scotland.gov.uk/Topics/marine/marine-environment/ mpanetwork/MPAParliamentReport); 2012.

[25] Countryside Council for Wales 2012. Marine conservation zone project wales [online], $\langle$ http://www.ccw.gov.uk/landscape-wildlife/managing-land-andsea/marine-policies/planningmanagement/marine-protected-areas/mcz-pro ject-wales.aspx?lang=en).

[26] SAC Management Group. The Moray Firth special area of conservation management scheme, revision two [online], 〈http://www.morayfirthpartner ship.org/assets/files/SAC\%20REV\%202/Rev2\%20MF\%20SAC\% 20MS\&AP-finalfirst\%20annual\%20review\%202010-amended\%20online.pdf); 2009.

[27] Davies B, Pita C, Lusseau D, Hunter C. The value of tourism expenditure related to the east of Scotland bottlenose dolphin population. Final report. Inverness: Moray Firth partnership [online], 〈http://morayfirth-partnership.org/assets/ files/Microsoft\%20Word\%20-

\%20The\%20Value\%20of\%20Tourism\%20Expendi ture\%20related\%20to\%20the\%20East\%20of\%20Scotland\%20.pdf); 2010. 67p.

[28] Community of Arran Seabed Trust (COAST) proposed marine protected area south coast of Arran [online], 2012. 40p.

〈http://arrancoast.com/website pdf/COAST Arran_South_MPA_proposal_9May_FinalP.pdf〉

[29] Howarth LM, Wood H, Turner AP, Beukers-Stewart BD. Complex habitat boosts scallop recruitment in a fully protected marine reserve. Marine Biology 2011;158(8):1767-80.

[30] Newman P, Lock K, Burton M, Jones J. Skomer marine nature reserve annual report 2011. Countryside council for Wales regional report CCW/WW/11/3; April 2012.

[31]Hoskin MG, Coleman RA, von Carlshausen L. Ecological effects of the Lundy No-Take Zone: the first five years (2003-2007). Report to Natural England, DEFRA and WWF-UK; 2009.

[32] Attrill MJ, Austen MC, Bayley DTI, Carr HL, Downey K, Fowell SC, et al. Lyme Bay-a casestudy: measuring recovery of benthic species; assessing potential 'spillover' effects and socioeconomic changes, 2 years after the closure. Response of the benthos to the zoned exclusion of bottom towed fishing gear and the associated socio-economic effects in Lyme Bay.Report to 
the Department of Environment, Food and Rural Affairs from the University of Plymouth. Plymouth: University of Plymouth Enterprise Ltd.; 2011.

[33]Mangi SC, Gall SC, Hattam C, Rees S, Rodwell LD. Lyme Bay-a case-study: measuring recovery of benthic species; assessing potential 'spillover' effects and socio-economic changes; 2 years after the closure. Assessing the socioeconomic impacts resulting from the closure restrictions in Lyme Bay.Final report. Report to the Department of Environment, Food and Rural Affairs from the University of Plymouth. Plymouth: University of Plymouth Enterprise Ltd.; 2011.

[34]Rees SE, Rodwell LD, Attrill MJ, Austen MC, Mangi SC. The value of marine biodiversity to the leisure and recreation industry and its application to marine spatial planning. Marine Policy 2010; 34:868-75.

[35] Rees SE, Austen MC, Attrill MJ, Rodwell LD. Incorporating indirect ecosystem services into marine protected area planning and management. International Journal of Biodiversity Science, Ecosystem Services and Management 2012; 8:272-85.

[36] Haines-Young $\mathrm{RH}$, Potschin MB. Methodologies for defining and assessing ecosystem services. Final report, JNCC, project code C08-0170-0062; 2009. 69p.

[37] Scottish Government. Guidelines on the selection of MPAs and development of the MPA network. Edinburgh: Scottish Government [online], 〈http://www.

scotland.gov.uk/Topics/marine/marine-environment/mpanetwork/mpaguidelines). 